Transportation Research Forum

A Transportation Performance Measurement System with a Mississippi Case Study

Author(s): Haiyuan Wang and Mingzhou Jim

Source: Journal of the Transportation Research Forum, Vol. 45, No. 3 (Fall 2006), pp. 19-37

Published by: Transportation Research Forum

Stable URL: http://www.trforum.org/journal

The Transportation Research Forum, founded in 1958, is an independent, nonprofit organization of transportation professionals who conduct, use, and benefit from research. Its purpose is to provide an impartial meeting ground for carriers, shippers, government officials, consultants, university researchers, suppliers, and others seeking exchange of information and ideas related to both passenger and freight transportation. More information on the Transportation Research Forum can be found on the Web at www.trforum.org. 


\title{
A Transportation Performance Measurement System with a Mississippi Case Study
}

\author{
by Haiyuan Wang and Mingzhou Jin
}

In current literature and practices, there are no systematic and user-oriented intermodal transportation performance measures. After identifying customer needs and transportation goals, this paper proposes a set of system-level performance measures for intermodal transportation that are user-oriented, scalable, systematic, and scientific. The measures can be used to compare intermodal design alternatives or to evaluate existing transportation systems with any size and any mode. The highway system in Mississippi is analyzed as a case study. The case study demonstrates the existing data sources, the methods of calculating the measures, and the means of evaluating transportation systems with the measures.

\section{INTRODUCTION}

With increased emphasis on intermodal transportation development, the issue of how to evaluate an intermodal transportation system has been receiving intensive attention since the enactments of the Intermodal Transportation Efficiency Act (ISTEA) (U.S. House of Representatives 1991) and the Transportation Equity Act for the 21st Century (TEA-21) (U.S. Department of Transportation 1998). The Government Performance and Results Act (U.S. Senate 1993) requires federal agencies to identify goals and measurable outcomes to gauge performance to meet program objectives. The ISTEA also requires all states to implement a performance-based planning process. The states of Minnesota, Oregon, Florida, and California have already enacted their own performance measurement systems. All administrations in the U.S. Department of Transportation (USDOT) also report performance measures for their transportation systems. For example, Maritime Administration reported port performance measures in 2003 and 2005 (Maritime Administration 2005). Additionally, U.S. Class I railroads report three measures: cars on line, train speed, and terminal dwell (hours) online at www. railroadpm.org. However, Vantuono (2005) reports that the railroads actually use different ways to calculate the measures, and it is difficult to compare them on a railroad-by-railroad basis.

Although numerous performance measures are presented in the literature, there is no systematic measurement system to evaluate intermodal transportation alternatives. Most existing measures can be applied only to a single mode. The administration structure of the USDOT partially causes the problem. Different administrations, organized based on modes, develop their own performance measures separately. For instance, the safety in airborne transportation is usually measured by the number of accidents per takeoff. It is not comparable with the highway accident rate, which is defined as the number of casualties per million passenger miles. Rutherford (1994) points out the measures defined for highway, or any single mode, cannot lead to multimodal solutions.

Performance measures are used to evaluate how well a system can satisfy its users/customers. Transportation engineers, state Departments of Transportation (DOTs), Metropolitan Planning Organizations (MPOs), and other practitioners are not users, though they design, build, operate, and manage transportation systems. However, most existing transportation measures are developed from the perspective of decision-makers instead of transportation users. Furthermore, current transportation measures have many overlaps and oversights. For instance, accessibility of intermodal facilities and connectivity between modes are usually listed along with mobility that is usually defined by the average travel time per trip. However, the former two are factors influencing mobility rather than measures for an overall system. A good intermodal transportation performance measurement system should meet the following criteria: 
- It should be applicable for all modes and their combinations.

- It should be based on user needs. Transportation systems are built for their users rather than others.

- It should be scalable to compare systems of different sizes.

- It should be scientific and systematic. A good performance measure system should be a hierarchy with system and subsystem measures. At the system level, there should be no overlaps or oversights.

- It should be as quantitative as possible. Though it is difficult to quantify all performance measures, such as comfort, quantitative measures can help to scientifically compare alternatives.

Well-defined transportation performance measures can be used for decision-making in various contexts such as policy analysis, resource allocation and programming, tradeoff analysis, corridor and project-level analysis, system operation, and ongoing monitoring and evaluation (Pickell and Neumann 2001). For example, the Minnesota DOT spent more than two years on aligning customer needs, outcomes, strategic objectives, targets, and measures for investment decision-making. The San Diego Metropolitan Transit Development Board uses performance measures to guide its most critical decisions on deployment service (Kassoff 2001).

After a literature review, this paper presents a set of user-oriented, scalable, systematic performance measures followed by a case study. Because of lack of data, the case study uses only highway freight data within a state. The purpose of the case study is to demonstrate how to collect data from existing sources, how to calculate the measures, and how to evaluate transportation systems based on the measures.

\section{LITERATURE REVIEW}

Hagler Bailly Services, Inc. (2000) groups transportation performance measures into eight main categories: mobility and accessibility, reliability, safety and security, environmental impact, cost effectiveness, infrastructure conditions, economic impact, and industry productivity.

Meyer (2001) defines mobility as the ability to transport goods and people in an efficient way measured by average origin-destination travel time per trip. Bertini et al. (2002) and Shaw (2002) consider average speed as mobility, while the Albany metropolitan area uses both speed and trip length (Meyer 2001). Colorado's performance measurement system (BRW 2000) defines Passenger (Freight) Mobility Coefficient as PMT (FTMT) $\times$ average speed/1,000,000, where PMT (FTMT) stands for passenger (freight ton) miles traveled. BRW (2000) and Bertini et al. (2002) use Passenger Mobility Index and Freight Mobility Index. The Passenger Mobility Index is $(\mathrm{PMT} / \mathrm{VMT}) \times$ average speed, where VMT stands for vehicle miles traveled. Similarly, the Freight Mobility Index is FTMT/ truck VMT $\times$ average speed. A mobility index can be used to compare different modes, but it favors public transportation because of its large loading efficiency. The American Transportation Research Institute (ATRI) explores methods for measuring freight performance on highways and concludes that positioning data from trucks can provide average travel rates along major U.S. freight corridors (Jones et al. 2005). Schrank and Lomax (2005) evaluate 85 U.S. urban areas with the Travel Time Index (TTI) and the delay per traveler. The TTI is the ratio of peak period travel time to free-flow travel time.

Accessibility is another major concern discussed in the literature. Bertini and El-Geneidy (2003) consider the amount of goods and the number of people accessing the system. The percentage of urban population within $X$ miles of transit is commonly used to evaluate the accessibility of transit service (BRW 2000, Metropolitan Transportation Commission 2001, and Dumbaugh and Meyer 2003). The percentage of employment sites within $X$ miles of major highways is another similar factor used for the San Francisco Bay Area to evaluate accessibility or connectivity (Metropolitan Transportation Commission 2001). The accessibility measures are major factors influencing the average total travel time. This paper's proposed measurement system considers accessibility to be a second-tier measure because the mobility index includes accessibility. 
BRW Inc. (2000) and Bertini et al. (2002) use vehicle miles traveled (VMT), person miles traveled (PMT), and the ratio of PMT/VMT to represent capacity. For freight transportation analysis, truck vehicle miles traveled, truck freight ton-miles traveled, and truck freight ton-miles traveled/ truck vehicle miles traveled are used as capacity measures (BRW Inc. 2000). Vehicle hours traveled and passenger hours traveled are considered to be passenger transportation capacity by Bertini et al. (2002) and Shaw (2002). Passenger hours traveled can be calculated by using VMT and the average vehicle occupancy (AVO). BRW Inc. (2000) also uses truck freight ton-miles traveled (TMT) to represent capacity. In fact, all the above capacity definitions are actually throughput. Capacity should be defined as maximal throughput. Because higher capacity usually means higher mobility for given traffic demand, capacity is a factor influencing mobility rather than a system-level measure.

Transportation reliability is usually measured by delays caused by unusual events or incidents such as accident delays, intersection delays, intermodal terminal delays or other lost time. There are several measures for delays, such as transferring time between modes (Hagler Bailly Services 2000, Bertini et al. 2002, and Czerniak et al. 1996), delays per ton-mile, lost time or delay time, congested highway miles divided by total highway miles (BRW Inc. 2000), and annual delay per traveler (Schrank and Lomax 2005). Travel time reliability is proposed by the Washington DOT (2003) to determine the best available tools and methods for collecting travel time data on a realtime basis. BRW Inc. (2000) uses the level of congestion to measure reliability. On-time percentage is considered a major measure of transportation system reliability, especially for transit systems (Cambridge Systematics 2000). The state of Florida also uses frequency of transit service to evaluate transit systems (Cambridge Systematics 2000).

Safety in highway transportation is commonly measured by fatalities and injuries per 100 million VMT, while the measure for airborne transportation is fatal aviation accidents per 100,000 departures (U.S. Department of Transportation 2002). Maritime safety is determined by the number of recreational boating fatalities per year, the number of calls for help received by the Coast Guard, and the percent of all mariners in imminent danger who are rescued. A common safety measure for railroads is train accidents per million train-miles and rail-related fatalities per million trainmiles. Transit transportation safety is measured by transit fatalities or injured people per 100 million passenger-miles traveled. All the above safety measures are defined for a single mode, and no existing measure can be used to compare the safety of systems having multiple transportation modes.

In the long run, the sustainability of a transportation system is affected by its impact on the environment (Ministry of Environment and Energy and National Environmental Research Institute 2000). Several state DOTs use tons (in millions) of mobile source emissions from on-road vehicles as one major measure (MEE and NERI 2000). Some studies define environment-related measures based on emission types. For example, the USDOT uses metric tons (in millions) of carbon-equivalent emissions or greenhouse gas emissions from transportation sources. The U.S. Environmental Protection Agency (EPA) determines transportation impacts on the environment based on criteria of pollutants. FHWA calculates total emissions per vehicle mile. A significant amount of pollution results from waterborne and pipeline transportation, and the gallons spilled per ton-mile can be used to measure environmental impact. Noise is another pollution caused by transportation. The USDOT (2003) uses the number of people who are exposed to a significant noise level as the measure.

The cost of highway freight per ton-mile is identified by Hagler Bailly Services, Inc. (2000), Hickling Lewis Brod, Inc. (1998), and the Florida DOT (1998) to measure the direct freight operation cost. Labor cost and fuel consumption cost are two major parts of the total operation cost. Truck technology and drivers' wages are used by Hagler Bailly Services, Inc. (2000) and the Florida DOT (1998) as system-level measures. Dollars per vehicle hour are used to represent longterm cost efficiency by Hagler Bailly Services, Inc. (2000) without considering the loading factor for freight transportation or vehicle occupancy for passenger transportation. Transportation facility maintenance also incurs direct cost.

The number of bridges and the number of deficient bridges per 100 miles are used by BRW Inc. (2000) to measure highway infrastructure condition. The lane-miles of highway requiring 
rehabilitation are used by the California DOT (1998) to denote the infrastructure condition. The Michigan DOT uses the percentage of miles of state trunk lines with a surface condition classified as good and the number of bridges rated as good (Act 51 Transportation Funding Study Committee 1999). Similar concepts may be applied for other modes. For example, the percentage and total length of different grades of railroad infrastructure are used to evaluate railway infrastructure (Act 51 Transportation Funding Study Committee 1999). In general, infrastructure performance measures discussed in the literature are not direct performance measures but some factors affecting travel time and maintenance cost.

Regarding economic impact, the number of direct and indirect jobs created by transportation construction and operation is considered one economic impact measure (INDOT 2000 and EastWest Gateway Coordinating Council 1998). Contribution of investment to GDP growth is another measure (Hickling Lewis Brod, Inc. 1998). The state of Florida uses revenue per ton-mile by mode to measure economic development (FDOT 1998). This benefit is an indirect monetary benefit of a transportation system and is related to mobility. The values of freight moved from, to, and within a region are used by St. Louis Region MPO (East-West Gateway Coordinating Council 1998) as economic performance measures. In fact, the value that a freight transportation system carries is primarily decided by freight transportation needs and has little relationship with transportation performance.

Industry productivity refers to the efficiency of the transportation industry instead of transportation systems in the literature. Thompson (2001) uses vehicle miles per capita, passenger trips per capita, revenue hours per employee, and passenger trips per employee to evaluate industry productivity. The FHWA (1993) measures transportation industry productivity by empty/loaded ratio for truck moves, annual miles per truck, and average length of haul by vehicle. We believe this set of performance measures does not directly address the performance of a transportation system.

\section{PROPOSED PERFORMANCE MEASURES}

\section{Transportation Users}

Transportation users include all agencies and participants in transportation systems that have diverse purposes, preferences, and requirements. The definition of transportation users in this paper is broader than passenger and freight shippers.

- Investors include transportation investors and stakeholders, which are sometimes government agencies. Their major concerns are how to develop a cost-effective system and how to recoup the investment as soon as possible.

- Industries include public and private industries. Their major concerns are transporting their goods and passengers in a quick, safe, cheap, reliable, profitable, and efficient manner.

- Individual users have major interests similar to those of industries.

- Society users' (or the public's) major concerns are economic impact, community impact, and environment considerations.

\section{Transportation Goals}

The following objectives for transportation systems are identified to address the needs of transportation users:

1. Mobility and Reliability objectives include reducing transportation time and avoiding delaysmajor concerns of most transportation users.

2. Safety objectives related to transportation safety and security include improving traffic safety, i.e. reducing traffic accident rates, injuries, fatalities, and risks. Objectives also include increasing traffic security and reducing crime rates, improving accident detection and response, and increasing public security and homeland security. 
3. Environmental Impacts objectives include reducing the amount of transportation-related pollutants, promoting the community livability near major transportation infrastructures, and decreasing energy consumption.

4. Direct Cost Efficiency objectives include developing cost-efficient transportation systems that have low cost/benefit ratios and high sustainability.

5. Economic Growth objectives include promoting local or regional economic growth and increasing local or regional employment opportunities.

Freight and passenger transportation systems should have similar (but not identical) performance measures with different units because their users have similar needs. Note that this paper does not intend to compare a freight transportation system to a passenger transportation system.

\section{Proposed Intermodal Transportation Performance Measurement System}

Performance measures should be developed in response to goals (Pickell and Neumann 2001). Several concepts must be clarified before a new intermodal measurement system is presented. TMR denotes ton-miles required, where the miles are the geographic distance instead of the actual distance traveled. For one customer who wants to move goods from point A to point B, transportation needs should be measured by the geographic distance between the two points. In other words, the customer wishes to minimize the total transportation time rather than the average speed. In Figure 1, two possible designs for freight transportation between A and B are assumed to have the same cost. Design 2 is a high-level highway, so its traveling speed is higher than that in Design 1. However, Design 1 may have better mobility for the users because of less travel time resulting from a shorter traveling distance while meeting the same transportation need measured by geographic distance. Mobility is used to measure how a transportation system moves freight and passengers, based on customers' needs, in less time rather than with higher vehicle speed. This statement is also justified by the study on a logistics network of a major automotive maker (Jin et al. 2006). The company pays transportation charges based on the geographic distance between the plant and its dealers rather than the actual distance traveled by trucks. The company does not care which routes the transportation service providers choose. Its major concern is how to ship cars from plants to dealers quickly, safely, and cost-effectively. For passenger transportation, transportation needs can be represented by passenger-miles required (PMR).

Figure 1: Geographic Distance Between Origin and Destination

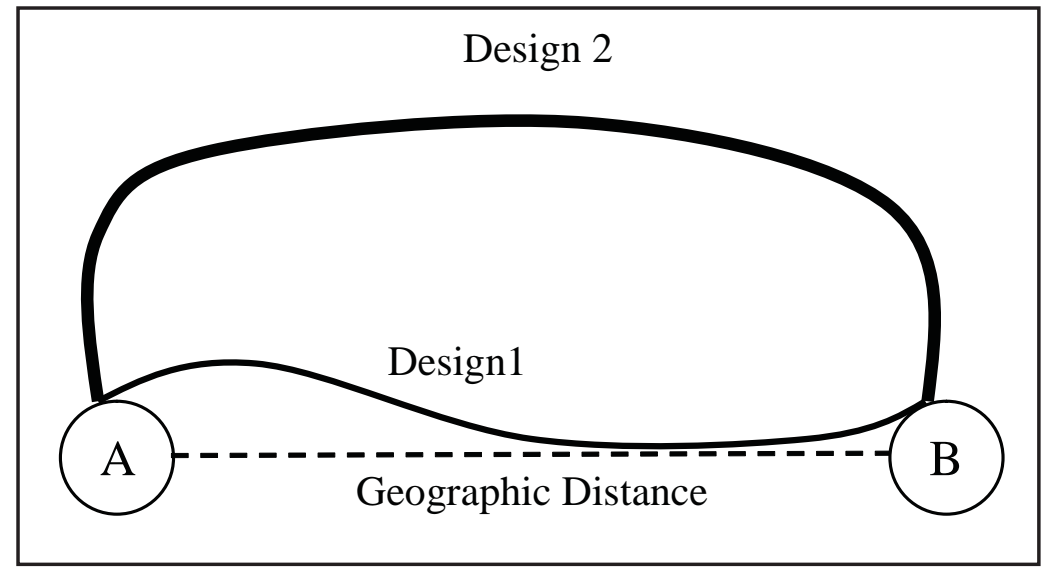


Performance Measures

\section{Mobility and Reliability}

(1) Mobility $(M)$ : Average travel time per mile required, where unit distance is geographic distance rather than traveling distance. For a system, mobility $M$ can be obtained by the following statistics:

$$
M=\frac{\sum_{(i, j, n) \in R} p_{i, j, n} T_{i, j, n}}{\sum_{(i, j, n) \in R} p_{i, j, n} l_{i, j}} .
$$

One trip is characterized by $(i, j, n)$, where $i$ is the origin, $j$ is the destination, and $n$ is the index of the trip for the OD $(i, j) . R$ is the set of all trips in the system, $l_{i, j}$ is the geographic mileage from $i$ to $j, p_{i, j, n}$ is tons (people for passenger transportation) involved in trip $(i, j, n)$, and $T_{i, j, n}$ is the total traveling time of trip $(i, j, n)$, which includes the time in all modes and the time for transfer between modes and access to a transportation facility. Accessibility is not a systematic performance measure because it is covered by mobility, which is defined by the total travel time from an origin to a destination per TMR or PMR. Capacity is not a performance measure, since it is not a users' need and is covered by mobility and reliability defined as follows. With the same demand, higher capacity usually results in better mobility.

(2) Reliability $(R)$ is the dependable levels of transportation service and is defined as the coefficient of total variation of travel time per TMR or PMR:

$$
R=\frac{\sqrt{\frac{\sum_{(i, j, n) \in R} p_{i, j, n} l_{i, j}\left(\frac{T_{i, j, n}}{l_{i, j}}-M\right)^{2}}{\sum_{(i, j, n) \in R} p_{i, j, n} l_{i, j}}}}{M} .
$$

Smaller $R$ means people can more easily predict total travel time and further avoid or reduce delays. Even if a trip takes much time, people can avoid delay by departing early when the traveling time has low variability. Though big disasters such as the Sept. 11 terrorism attack or Hurricane Katrina do not happen often; they have a large impact on reliability due to their large resulting variances. More transportation alternatives can alleviate transportation impacts of disasters and improve the overall reliability of a transportation system. A part of the total variance is predictable, while the remaining is not. Another reliability measure $R_{u}$ is defined as the coefficient of unpredicted variation of travel time per TMR or PMR:

$$
R_{u}=\frac{\sqrt{\frac{\sum_{(i, j, n) \in R} p_{i, j, n} l_{i, j}\left(\frac{T_{i, j, n}-f_{i, j, n}}{l_{i, j}}\right)^{2}}{\sum_{(i, j, n) \in R} p_{i, j, n} l_{i, j}}}}{M} .
$$

$f_{i, j, n}$ is the expected travel time for trip $(i, j, n)$, which is calculated with all known information. $R_{u}$ is the primary reason for delays or inconvenience. In traditional transportation engineering, a common performance measure is delay that includes recurring delays and nonrecurring delays. Recurring delays happen regularly and are predictable. We believe reliability $R$ and $R_{u}$ defined above are more scientific and can cover all delays. With $M$, the mobility, as the divider, reliability $R$ and $R_{u}$ are also scalable and can be used to compare systems with different sizes and features. 
Safety

(1) Fatality Rate $\left(S_{F}\right)$ : Number of fatalities per TMR or PMR that can be estimated by:

$$
S_{F}=\frac{\sum_{(i, j, n) \in R} F_{i, j, n}}{\sum_{(i, j, n) \in R} p_{i, j, n} l_{i, j}} .
$$

$F_{i, j, n}$ is the fatalities in trip $(i, j, n)$, and $\sum_{(i, j, n) \in R} p_{i, j, n} l_{i, j}$ is the total TMR for freight transportation or the total PMR for passenger transportation.

Injury Rate $\left(S_{I}\right)$ : Number of injuries per TMR or PMR

Different modes have different accident outcomes. An airplane crash may result in more fatalities, rather than injuries, than a highway car accident. The number of injuries per TMR or PMR can be estimated by:

$$
S_{I}=\frac{\sum_{(i, j, n) \in R} I_{i, j, n}}{\sum_{(i, j, n) \in R} p_{i, j, n} l_{i, j}} .
$$

$I_{i, j, n}$ is the number of injuries in trips $(i, j, n)$. Safety also has a large impact on delay. Lindley (1987) estimates that over $60 \%$ of the congestion delay experienced on urban freeways is caused by incidents rather than recurring congestion. In this measure system, this effect is included in reliability.

\section{(3) Property Damage Rate $\left(S_{p}\right)$}

In addition to loss of human lives and health, transportation accidents also cause property damage. $S_{p}$ is used to capture this effect:

$$
S_{p}=\frac{\sum_{(i, j, n) \in R} D_{i, j, n}}{\sum_{(i, j, n) \in R} p_{i, j, n} l_{i, j}} .
$$

$D_{i, j, n}$ is property damage caused by accidents in trips $(i, j, n)$. In the literature, accident detection and response efficiency are common safety measures, but they have been covered by mobility and reliability. Therefore, the safety measures in this paper do not consider congestion caused by accidents.

\section{Environmental Impacts}

The primary environmental impact measures are energy consumption, transportation-related pollutants released, and community livability near major transportation infrastructures.

(1) Energy Consumption (EC): Average unsustainable energy consumption (BTU) per TMR or PMR. The value of $E C$ can be estimated by: 
Performance Measures

$$
E C=\frac{\sum_{(i, j, n) \in R} E_{i, j, n}}{\sum_{(i, j, n) \in R} p_{i, j, n} l_{i, j}} .
$$

$E_{i, j, n}$ is the total unsustainable energy consumed by $n$th trip from origin $i$ to destination $j$. Unsustainable energy sources, such as gas, oil, and coal, cannot be renewed and have a larger negative impact on the environment than renewable energy sources such as solar energy, wind power, and hydrogen. The energy consumption is defined from the perspective of environmental impact rather than operation cost, which will be included in cost effectiveness. Fuel is only part of the energy consumed by freight/passenger travel. A significant amount of energy is used to produce and maintain vehicles. This energy is called "embodied energy" and also should be included in $E_{i, j, n}$.

(2) Pollutants released $(P)$ : Tons of emissions from transportation systems per TMR or PMR:

$$
P=\frac{\sum_{(i, j, n) \in R} p o_{i, j, n}}{\sum_{(i, j, n) \in R} p_{i, j, n} l_{i, j}} .
$$

$p o_{i, j, n}$ is the tons of mobile pollutants emissions caused by trip $(i, j, n)$. Only the total pollutants are considered a system-level measure.

(3) Community livability $(L)$ : percent of people whose lives are negatively affected by transportation:

$$
L=\frac{P_{a}}{P_{T}} .
$$

$P_{a}$ denotes the number of people whose lives are negatively affected by a transportation system, and $P_{T}$ denotes the total number of people using the transportation system. Though the impact on the community is rather subjective, a survey may help determine the percent of people who think they are negatively impacted by regional transportation. Here TMR or PMR are not used because $L$ is not from the viewpoint of passengers or freight shippers but from that of the community or society.

\section{Direct Cost Efficiency}

This measure considers the direct cost of a transportation system rather than a comprehensive cost model, including external costs such as environment impacts. The direct cost includes vehicle operation cost and transportation facility costs for construction, operation, maintenance, and disposal.

(1) Vehicle Operation Cost (VC): Vehicle operation cost primarily includes labor, fuel consumption, vehicle insurance, vehicle maintenance, and vehicle depreciation costs per TMR or PMR. This general cost index considers the life-cycle cost for vehicle operation and varies for different modes. Different components of transportation modes should be considered for each segment of a trip in an intermodal transportation system. The vehicle operation cost (VC) can be obtained by:

$$
V C=\frac{\sum_{(i, j, n) \in R}\left(L C_{i, j, n}+G C_{i, j, n}+V I_{i, j, n}+V M_{i, j, n}+V A_{i, j, n}\right)}{\sum_{(i, j, n) \in R} p_{i, j, n} l_{i, j}} .
$$


$L C_{i, j, n}$ is the labor cost, $G C_{i, j, n}$ is the fuel consumption cost, $V I_{i, j, n}$ is the vehicle insurance cost, $V M_{i, j, n}$ is the vehicle maintenance cost, and $V A_{i, j, n}$ is the associated vehicle depreciation cost in trip $(i, j, j$, n).

(2) Transportation Facility Cost (FC): The cost of transportation facility per TMR or PMR. A transportation system is usually designed to operate for decades. Different costs (e.g., maintenance costs) are incurred in different stages over a system's life cycle. Money flow diagrams and interest issues discussed in the area of Engineering Economics should be considered to calculate average cost per TMR or PMR. FC is defined as:

$$
F C=\frac{A T C}{\sum_{(i, j, n) \in A R} p_{i, j, n} l_{i, j}} .
$$

$A T C$ is annual equivalent total cost, and $A R$ is the set of total trips for one typical year.

\section{ECONOMIC GROWTH AND EMPLOYMENT IMPROVEMENT}

Because of the high cost involved in transportation design, construction and operation, local governments aggressively seek financial support for transportation projects to improve local business sales and employment.

(1) Economic growth $(E G)$ : the business sales increase caused by a million-dollar transportation investment that includes initial capital investment and operating and maintenance investment. EG can be obtained by:

(12) $E G=\frac{T E G}{T I}$.

TEG is total economic growth contributed by a transportation system and $T I$ is the total investment of the transportation system.

(2) Regional Employment Improvement ( $J$ ): number of job year opportunities created by a one million-dollar transportation investment. Transportation-related construction and maintenance can create a large number of jobs. Some of the jobs may last several years, while others are available only for a relatively short time. Therefore, the employment improvement should be measured by job years as:

$$
J=\frac{T J}{T I}
$$

$T J$ is the total created job years due to the transportation system. These measures are developed from the perspective of government agencies or society rather than passengers or industries. Thus, they are defined based on investments rather than TMR or PMR.

\section{A CASE STUDY OF PROPOSED PERFORMANCE MEASURES}

In this section, a case study is presented to demonstrate the procedures to calculate the proposed performance measures. The state of Mississippi is used because of data availability to the authors. Mississippi has 82 counties as shown in Figure 2. This study divides the state into the southern region and northern region. The highway system in terms of carrying the within-region traffic is evaluated based on the proposed measures. The within-region traffic has both origin and destination in the state. 
Performance Measures

Figure 2: Northern Region and Southern Region of Mississippi and Its Highway Network

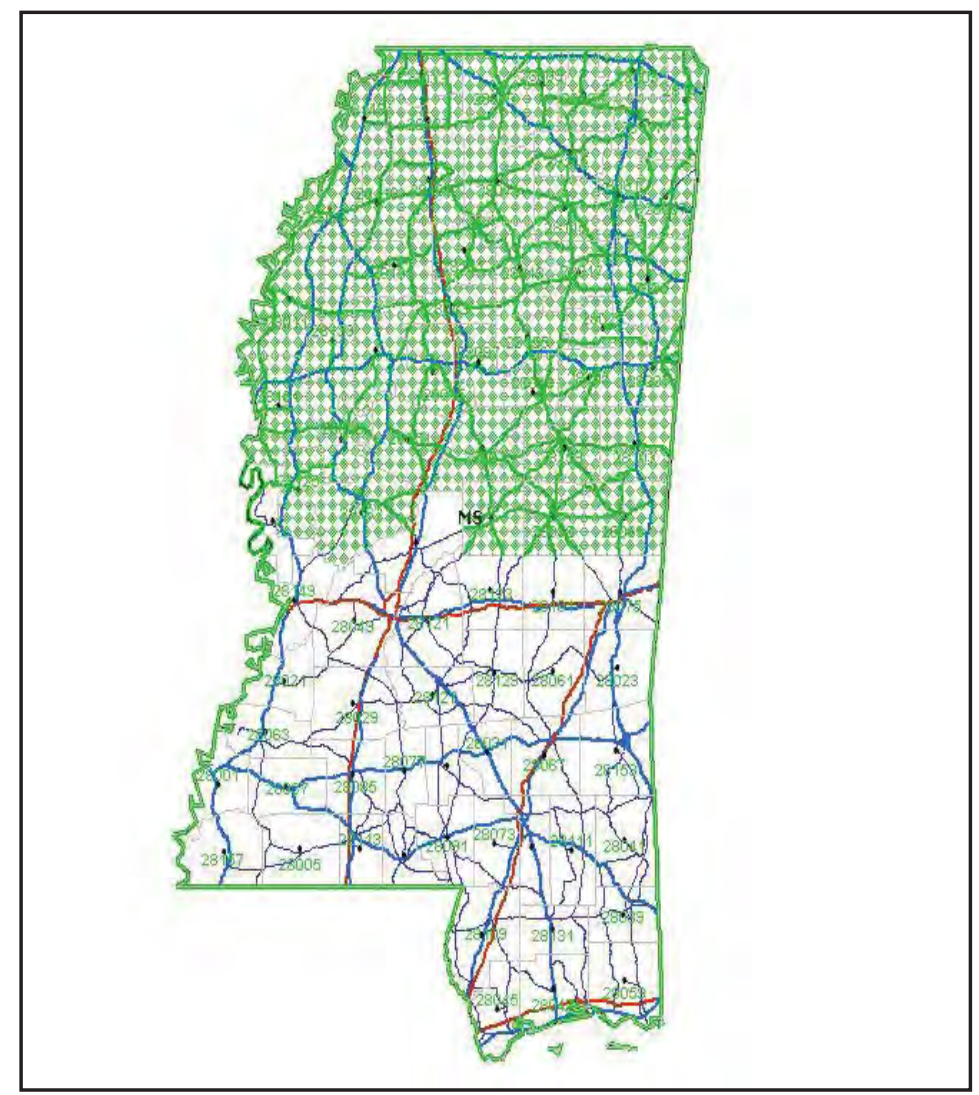

\section{Truck Traffic Demand Data Sources}

The truck O\&D demand data are derived from the within-region traffic O\&D results from the study of "Intermodal Freight Transportation Planning Using Commodity Flow Data" (Zhang et al. 2003), which is based on the Commodity Flow Survey (CFS) 1997 data. There are four components of truck traffic O\&D data: Internal-Internal (within-region), External-Internal, Internal-External, and External-External. Only the within-region O\&D traffic is used in this paper because it is difficult to know the access points for the external traffic to enter/leave the state. Within-region trucks accounted for $10.14 \%$ of highway trucks in Mississippi (Zhang et al. 2003). County-level data in or near 1997 will be used for consistency. In 1997, the within-region traffic in Mississippi was 65.86 billion ton-miles.

\section{Performance Measure Calculation}

This section presents how the proposed performance measures can be obtained.

Mobility and Reliability. The numerator in equation (1) is obtained through the following procedures: 1) document the highway transportation network in the state; 2) obtain within-region O\&D data of the region in 1997; 3) assign O\&D data on the transportation network to obtain the traffic volume on each highway segment; 4) calculate travel time on each highway segment; 5) calculate total ton-hours carried on the networks of each region. 
The traffic on each link in the network is obtained through traffic assignment based on the shortest path rule by using TransCAD (Caliper Corporation 2001), a leading transportation planning software package. TransCAD determines the shortest time path between origin and destination points and assigns all the trips between the origin and destination to that path. The total ton-hours in the two regions are calculated by the sum of the loads on the links. Alternatively, the total tonhours can be obtained by the sum of ton-hours of each individual trip as shown in equation (1), but a costly large transportation survey is required to obtain ton-hours of each trip. The total ton-miles required (TMR) in each region, the denominator in equation (1), is obtained based on the manually calculated geographic distance of each O\&D pair in TransCAD and O\&D demand. If the origin and destination of one O\&D pair is not in the same region, for either region, only distance of the O\&D pair that actually lies in the region is added into the TMR for that region. The mobility indices in the northern and southern regions are $2.130 \times 10^{-2}$ and $1.999 \times 10^{-2}$ hour per TMR, respectively (Table 1 ). We conjecture that the worse mobility in northern Mississippi is caused by its lower accessibility to high-level highways. More attention should be paid to the northern region if equal regional mobility is desirable. No current data are available to obtain the proposed reliability index. Therefore, a large-scale comprehensive survey may be necessary to calculate reliability, but it is too costly for this study.

Safety and Security. The number of fatalities is obtained from the fatality analysis reporting system (FARS) in the web-based encyclopedia maintained by the National Center for Statistics and Analysis (NCSA) and the USDOT (2004). The FARS contains data on all crashes that occur on public roadways. A query is conducted to obtain the number of fatalities in each Mississippi county. After aggregation, total fatalities in both regions are obtained. Another query is conducted for the total fatalities in the U.S. by vehicle types. FARS statistics shows that truck-related fatalities account for $41.2 \%$ of the U.S. total highway accident fatalities in 1997. This percentage is used to calculate the total number of fatalities caused by truck movements. Within-region trucks accounted for 10.14\% of highway trucks in Mississippi (Zhang et al. 2003). To be consistent with the mobility analysis, 1997 data are used to calculate the fatality index for within-region truck movement. The northern and southern regions have fatality indices of $1.294 \times 10^{-11}$ and $1.038 \times 10^{-11}$ fatalities per TMR (Table 1). Southern Mississippi had better performance in 1997 with a lower fatality index.

The total number of injuries is obtained from the FARS. There were 2,014 highway accident injuries in 1997 in the state. Alternatively, the injury data can be obtained from the Trucks Involved in Fatal Accidents (TIFA) database, one of the intermodal transportation databases maintained by the Bureau of Transportation Statistics (BTS) (2005a). To be consistent, the factor $(0.1041 \times 0.412)$, which is used in calculating the fatality index, is used to convert total injuries into those caused by within-region truck traffic. In 1997, the northern and southern regions have injury rate indices of $2.948 \times 10^{-11}$ and $2.403 \times 10^{-11}$ injuries per TMR, respectively (Table 1 ). Therefore, in terms of the injury index, southern Mississippi has better performance.

There is no database available to calculate property damage cost. Safety measure indices for other transportation modes may be obtained by using the following databases. The Railroad Accident/Incident Reporting System (RA/IRS) (BTS 2005b) maintained by the BTS provides data for railway safety analysis. The Aviation Accident Statistics and the Aviation Safety Reporting System (ASRS) (National Aeronautics and Space Administration 2004) maintained by the BTS have data to calculate the aviation safety measure. The Marine Casualty and Pollution Database (MCPD) (BTS 2005c) can be used to calculate marine safety statistics. 
Performance Measures

Table 1: Indices of Performance Measures

\begin{tabular}{|c|c|c|c|c|c|c|c|c|c|}
\hline \multicolumn{10}{|c|}{ Mobility $(M)$} \\
\hline Region & \multicolumn{2}{|c|}{\begin{tabular}{|l|}
$\begin{array}{l}\text { Total Ton-Hour of WRTT } \\
\text { (ton-hours) (1) }\end{array}$ \\
\end{tabular}} & \multicolumn{4}{|c|}{$\begin{array}{l}\text { Total Ton-mile Required of WRTT } \\
\text { (ton-miles required) (2) }\end{array}$} & \multicolumn{3}{|c|}{$\begin{array}{l}\text { Mobility Index }(M) \text { (hours per mile } \\
\text { required) }(1) /(2)\end{array}$} \\
\hline Northern & \multicolumn{2}{|c|}{$29,248,448,124$} & \multicolumn{4}{|c|}{$1,390,718,155,840$} & \multicolumn{3}{|c|}{$2.130 \times 10^{-2}$} \\
\hline Southern & \multicolumn{2}{|c|}{$36,608,365,399$} & \multicolumn{4}{|c|}{$1,831,294,202,878$} & \multicolumn{3}{|c|}{$1.999 \times 10^{-2}$} \\
\hline \multicolumn{10}{|c|}{ Fatality $\left(S_{F}\right)$} \\
\hline Region & \multicolumn{2}{|c|}{$\begin{array}{l}\text { Fatalities Caused by Truck } \\
\text { Traffic (1997) (1) }\end{array}$} & \multicolumn{2}{|c|}{$\begin{array}{l}\text { Fatalities Caused } \\
\text { by WRTT }(2)=(1) \\
\times 0.1014\end{array}$} & \multicolumn{3}{|c|}{$\begin{array}{l}\text { Total TMR } \\
\text { (millions of ton-miles } \\
\text { required) (3) }\end{array}$} & \multicolumn{2}{|c|}{$\begin{array}{l}\text { Fatality Index }\left(S_{F}\right) \text { (fatalities } \\
\text { per TMR) }(2) /(3)\end{array}$} \\
\hline Northern & \multicolumn{2}{|l|}{171} & \multicolumn{2}{|c|}{$\begin{array}{r}18 \\
\end{array}$} & \multicolumn{3}{|c|}{$1,390,718$} & & $1.294 \times 10^{-11}$ \\
\hline Southern & \multicolumn{2}{|l|}{185} & \multicolumn{2}{|r|}{19} & \multicolumn{3}{|c|}{$1,831,294$} & & $1.038 \times 10^{-11}$ \\
\hline \multicolumn{10}{|c|}{ Injury Rate Index $\left(S_{I}\right)$} \\
\hline Region & \multicolumn{2}{|c|}{$\begin{array}{l}\text { Injuries Caused by Truck } \\
\text { Traffic (1997) (1) }\end{array}$} & \multicolumn{3}{|c|}{$\begin{array}{l}\text { Injuries Caused by } \\
\text { WRTT }(2)=(1) \times \\
0.1014\end{array}$} & \multicolumn{2}{|c|}{$\begin{array}{l}\text { Total TMR } \\
\text { (millions of ton-miles } \\
\text { required) (3) }\end{array}$} & $\begin{array}{l}\text { Injury } \\
\text { per Ts }\end{array}$ & $\begin{array}{l}\text { Index }\left(S_{I}\right) \text { (injuries } \\
\text { MR) }(2) /(3)\end{array}$ \\
\hline Northern & \multicolumn{2}{|l|}{402} & \multicolumn{2}{|r|}{41} & \multicolumn{3}{|c|}{$1,390,718$} & & $2.948 \times 10^{-11}$ \\
\hline Southern & 428 & & & 44 & & 1,831 & 294 & & $2.403 \times 10^{-11}$ \\
\hline Transport & ation Pollutants Inder & $\mathrm{x}(P)$ & & & & & & & \\
\hline Region & $\begin{array}{l}\text { Total Pollutants Gene } \\
\text { by Truck Traffic (199 } \\
\text { tons) (1) }\end{array}$ & $\begin{array}{l}\text { erated } \\
6 \text {, }\end{array}$ & $\begin{array}{l}\text { Total } \\
\text { Gener } \\
(1996 \\
\times 0.10\end{array}$ & $\begin{array}{l}\text { ollutants } \\
\text { ated by WRT } \\
\text { tons) }(2)=(1 \\
4\end{array}$ & & $\begin{array}{l}\text { tal TN } \\
\text { illions } \\
\text { quired) }\end{array}$ & $\begin{array}{l}\text { IR } \\
\text { of ton-miles } \\
\text { (3) }\end{array}$ & & $\begin{array}{l}\text { ransportation } \\
\text { ollutants Index }(P) \\
\text { ons per TMR) (2)/(3) }\end{array}$ \\
\hline Northern & 2824.637 & & & 286.418 & & & 390,718 & & $2 . .059 \times 10^{-10}$ \\
\hline Southern & 3744.575 & & & 379.700 & & & 831,294 & & $2.073 \times 10^{-10}$ \\
\hline Vehicle $\mathbf{O}$ & eration Cost Index ( & $V C)$ & & & & & & & \\
\hline Region & $\begin{array}{l}\text { Total VMT of WRTT } \\
\text { (vehicle miles travele }\end{array}$ & d) (1) & $\begin{array}{l}\text { Total } \\
\text { Cost }( \\
0.591\end{array}$ & $\begin{array}{l}\text { Vehicle Oper } \\
\text { dollars) }(2)=\end{array}$ & & $\begin{array}{l}\text { tal TN } \\
\text { illions } \\
\text { quired) }\end{array}$ & $\begin{array}{l}\text { of ton-miles } \\
\text { (3) }\end{array}$ & & $\begin{array}{l}\text { ehicle Operation Cost } \\
\text { dex (VC) (dollars per } \\
\text { MR) (2)/(3) }\end{array}$ \\
\hline Northern & $96,722,000,00$ & & & $7,162,702,0$ & & & 390,718 & & $4.111 \times 10^{-2}$ \\
\hline Southern & $128,992,000,00$ & & & $6,234,272,0$ & & & 831,294 & & $4.163 \times 10^{-2}$ \\
\hline Transpor & ation Facility Cost In & $\operatorname{dex}(F$ & & & & & & & \\
\hline Region & $\begin{array}{l}\text { Total Lane Miles of } \\
\text { Highways (1) }\end{array}$ & $\begin{array}{l}\text { Cost } \\
\text { Sing } \\
\text { Mile } \\
(2)\end{array}$ & $\begin{array}{l}\text { Per } \\
\text { Lane } \\
\text { (dollar) }\end{array}$ & $\begin{array}{l}\text { Total Hig } \\
\text { Facility C } \\
\text { (dollars) }\end{array}$ & $\begin{array}{l}\text { way } \\
\text { st } \\
)=(1) \times(2)\end{array}$ & $\begin{array}{l}\text { Tota } \\
\text { (mil } \\
\text { requ }\end{array}$ & $\begin{array}{l}\text { TMR } \\
\text { ions of ton-n } \\
\text { ired) (4) }\end{array}$ & miles & $\begin{array}{l}\text { Transportation } \\
\text { Facility Cost Index } \\
(F C) \text { (dollar per } \\
\text { TMR) (3)/(4) }\end{array}$ \\
\hline Northern & 9020.220 & & 43,135 & 10,311 & 29,190 & & $1,390,718$ & & $7.414 \times 10^{-3}$ \\
\hline Southern & 9780.920 & & 43,135 & 11,180 & 11,984 & & $1,831,294$ & & $6.105 \times 10^{-3}$ \\
\hline Economic & Growth Index (EG) & & & & & & & & \\
\hline Region & $\begin{array}{l}\text { Total Income } \\
\text { (thousands of } \\
\text { dollars 1996) (1) }\end{array}$ & $\begin{array}{l}\text { Total } \\
\text { (thous } \\
\text { dollar } \\
\text { (2) } \\
\end{array}$ & $\begin{array}{l}\text { icome } \\
\text { nds of } \\
1997) \\
\end{array}$ & $\begin{array}{l}\text { Highway } \\
\text { Economic } \\
(3)=[(2)-(1\end{array}$ & $\begin{array}{l}\text { ntribution } \\
\text { rowth (dol } \\
\times 0.03\end{array}$ & $\begin{array}{l}\text { to } \\
\text { llars) }\end{array}$ & $\begin{array}{l}\text { Total Invest } \\
\text { (millions of } \\
\text { dollars, } 199\end{array}$ & $\begin{array}{l}\text { tment } \\
f \\
\text { 97) (4) }\end{array}$ & $\begin{array}{l}\text { Economic Growth } \\
\text { Index }(E G)(3) /(4)\end{array}$ \\
\hline Northern & $19,317,969$ & 20,3 & 8,489 & & 15,600 & & 10,311 & & $2.969 \times 10^{-3}$ \\
\hline Southern & $29,580,003$ & 31,2 & 9,087 & & 72,500 & & 11,180 & & $4.505 \times 10^{-3}$ \\
\hline Regional & imployment Improve & ment I & $\operatorname{dex}(J)$ & & & & & & \\
\hline Region & Employment (1) & $\begin{array}{l}\text { Total } \\
1997)\end{array}$ & $\begin{array}{l}\text { ivestme } \\
\text { 2) }\end{array}$ & nt (dollars, & $\begin{array}{l}\text { Regional } \\
\text { of job }\end{array}$ & $\begin{array}{l}\text { Empl } \\
\text { years }\end{array}$ & $\begin{array}{l}\text { oyment Impr } \\
\text { per million d }\end{array}$ & $\begin{array}{l}\text { roveme } \\
\text { dollar i }\end{array}$ & $\begin{array}{l}\text { ent Index }(J)(\text { number } \\
\text { investment })(1) /(2)\end{array}$ \\
\hline Northern & 6,941 & & $0,311,3$ & 29,190 & & & 0.6 & 673 & \\
\hline Southern & 14,093 & & $1,180,9$ & 11,984 & & & & 260 & \\
\hline
\end{tabular}


Environmental Impact. The U.S. Emissions Inventory 1999 Report distributed by the U.S. Environmental Protection Agency (USEPA 1999) reported that a total of 1,605 million metric tons of carbon equivalent (MMTCE) greenhouse gas emissions were generated in the U.S. in 1997, of which 469.9 MMTCE were from transportation activities. Therefore, transportation movement accounted for $29.3 \%$ of the total emissions. In all the 469.9 MMTCE from transportation systems in 1997, trucks contributed 188.1 MMTCE (USEPA 1999). In other words, in the United States, about $40 \%$ of the total emissions from transportation systems were generated by trucks. Similar figures can be extracted for other transportation modes from the report. The total emission data of each county can be obtained by a query from the Access to Air Pollution Data (AirData) website maintained by the USEPA (2005). Since 1997 data for emissions in the state is unavailable, 1996 data is used. The emission report summarizes hazardous air pollutant (HAP) emissions from all sources by county. A similar aggregation procedure is performed to obtain an estimate of total emissions for both regions in Mississippi based on the general national figures. In terms of transportation environment impact, the northern region had a lower transportation pollutants index of $2.059 \times 10^{-10}$ tons per TMR, and the southern region's transportation pollutants index was $2.073 \times 10^{-10}$ tons per TMR (Table 1). MOBILE 6 , a software package distributed by the USEPA (2004), can also be used to estimate total pollutants based on actual vehicle miles traveled in the system. There is no existing data for the community livability index, and a survey would be necessary.

Long Term Transportation Cost Efficiency. Labor, fuel consumption, vehicle insurance, vehicle maintenance, vehicle depreciation, and other costs are involved in vehicle operations. Some of them are variable costs (also called out-of-pocket expenses) that depend on vehicle usage, such as fuel, oil, and tire wear, while others are fixed costs that are unrelated to how much vehicles are utilized. Labor cost difference could be significant when we compare two regions far away from each other. In this case study, we assume the northern region has the same labor costs as the southern region. Petroleum costs are major contributors to vehicle operation costs, and they depend on the transportation modes, gas prices, vehicle speed, and vehicle loads. The U.S. has much lower fuel prices and taxes than European countries (International Energy Agency 2000). Vehicle insurance costs, vehicle maintenance costs, and other overhead are well studied in the literature. Insurance costs are usually higher for new or large-sized vehicles. Maintenance costs are, in general, higher for older vehicles and depend on the surface and geometric condition of highway systems. Theoretically, the vehicle operating cost for the southern region and the northern region should be different, but there is no study in the two regions on this topic. On average, $81 \%$ of the trucks (Zhang et al. 2003) traveling in Mississippi were single-unit trucks in 1997. The other 19\% of the trucks were tractor-trailer trucks. The average vehicle operation cost per 1,000 miles traveled in Mississippi is derived based on the Weisbrod and Weisbrod (1997) study and the truck type distribution in the state. The result is $\$ 591$ per 1,000 miles traveled. For other modes, data need to be collected for a specific region before one conducts a cost analysis. The average payload of each vehicle in the state (Zhang et al. 2003) was 17.5 tons in 1997. Therefore, the total vehicle operation costs in northern Mississippi and in southern Mississippi are 4.111 $\times 10^{-2}$ and $4.163 \times 10^{-2}$ dollars per TMR, respectively (Table 1). The southern region had a higher vehicle operation cost per TMR. Although southern Mississippi had higher TMR, it also had a higher total VMT resulting in a higher total vehicle operation cost.

Transportation facility costs $(F C)$ correspond to construction and maintenance costs of transportation facilities, and construction incurs most of the expenditure. For highways, usually the cost is determined by construction cost per lane mile and total lane miles. To know whether the state of Washington has higher construction expenditures than other states, a survey on construction costs in other states was conducted by the Washington DOT (2002). Its results show average highway construction costs in Mississippi are \$1,033,576 per single lane mile. The survey report does not indicate the year of this estimate. According to the Highway \& Motorway Fact Book published by Public Purpose (2001), the maintenance cost is around $10.6 \%$ of the highway construction cost 
in 1996. Therefore, the total construction and maintenance cost in Mississippi is $\$ 1,143,135$ per single lane mile. The northern and southern regions have 9,020 and 9,780 lane miles of highway, respectively. Therefore, the facility costs for northern and southern Mississippi highways are $7.414 \times 10^{-3}$ and $6.105 \times 10^{-3}$ dollars per TMR, respectively (Table 1 ). The highways in southern Mississippi had lower transportation facility cost per TMR. As we can see from the derivation process of this index, all the difference is due to the total lane miles of highways and TMR. More study on the facility cost of both regions should be conducted to obtain more accurate data.

Economic Growth and Employment Improvement. As identified by many transportation professionals, transportation investments can stimulate economic growth. The economic growth stimulated by transportation projects is also influenced by the economic conditions of a specific region.

In 1997, the transportation industry contributed 3\% to the U.S. GDP (in 1996 dollars) according to the National Transportation Statistics 2002 (BTS 2003). County level total personal income data can be derived from a query from Detailed County Annual Tables of Income and Employment by SIC industry (1969-2001, CA30-CA45) in the Local Area Personal Income Database maintained by the Bureau of Economic Analysis (2003). Aggregated regional total personal income is obtained for the years of 1996 and 1997. Total investment of the highway networks is derived from the highway facility costs. The economic growth indices $(E G)$ of the northern and southern regions are $2.969 \times 10^{-3}$ and $4.505 \times 10^{-3}$, respectively (Table 1 ). Southern Mississippi has better performance based on the economic growth index.

Employment opportunities provided by transportation investments can be directly obtained for a specific project. To be more accurate, job years rather than the number of jobs created by transportation investments are used in this paper. The data for employment opportunities created by transportation-related projects are obtained from the Complete Economic and Demographic Data Source (CEDDS) (Woods and Pool Economics 2001). The employment improvement indices of the northern and southern regions are 0.673 and 1.260 job years per million dollars invested, respectively (Table 1). Transportation investments in southern Mississippi yielded a larger regional employment improvement than those in northern Mississippi.

\section{Performance Indices Comparison in the State}

Table 1 summarizes the indices of performance measures in both regions. Note that small values of some calculated indices are caused by the large TMR. The units of performance measures make the indices comparable for different sizes of transportation networks. In summary, southern Mississippi has better mobility, higher safety, slightly worse environmental impact performance, higher vehicle operation cost, lower transportation facility cost, and better performance in economic growth and employment improvement than northern Mississippi with regard to within-region truck traffic. To provide an overall judgment of which region has better performance, a model incorporating all the related costs must be built with a weight for each performance measure. Table 2 summarizes the data requirements and sources.

\section{Intermodal Aspect of the Case Study}

The case study evaluates only the highway performance of the two Mississippi regions. Similarly, the data of other modes can be collected from various sources, which are also discussed in the case study and summarized in Table 2. However, TransCAD does not have networks for other modes and does not have intermodal analysis capability (Zhang et al. 2003). To perform an intermodal transportation analysis, a simulation model similar to the Virtual Intermodal Transportation System (VITS) (Tan et al. 2004) should be developed. Some what-if questions can be answered by the simulation model. For example, if the commodity flow increases due to Latin American trade, what 
are the performances of the intermodal transportation systems in different regions and what kinds of projects are the most cost effective in response to the changes in transportation needs? Since the proposed performance measures are defined based on the users' needs and are applicable for all transportation modes, they can be directly used to evaluate an intermodal transportation system or an intermodal transportation design.

Table 2: Data Requirements and Sources

\begin{tabular}{|c|c|c|c|c|}
\hline \multicolumn{2}{|c|}{ Performance Measures } & Required Data & Sources & Other Possible Sources \\
\hline \multirow{3}{*}{$\begin{array}{l}\text { Mobility and } \\
\text { Reliability }\end{array}$} & $\begin{array}{l}\text { Mobility }(M) \\
\text { (hour per mile) }\end{array}$ & $\begin{array}{l}\text { Geographic OD data } \\
\text { Travel time data }\end{array}$ & $\begin{array}{l}\text { Statewide or regional } \\
\text { transportation } \\
\text { planning data, GIS } \\
\text { software }\end{array}$ & $\begin{array}{l}\text { TRANSEARCH data, } \\
\text { data, Ground counts data, } \\
\text { Commodity Flow Survey } \\
\text { data }\end{array}$ \\
\hline & \multirow{2}{*}{$\begin{array}{l}\text { Reliability } \\
(R, R u) \\
\text { (no unit) }\end{array}$} & $\begin{array}{l}\text { Travel time data } \\
\text { Data to obtain } M\end{array}$ & $\begin{array}{l}\text { Survey data collection } \\
\text { Data to obtain } M\end{array}$ & N/A \\
\hline & & $\begin{array}{l}\text { Travel time data } \\
\text { Data to obtain } M \\
\text { Expected travel time } \\
\text { data }\end{array}$ & $\begin{array}{l}\text { Survey data collection } \\
\text { Data to obtain } M\end{array}$ & N/A \\
\hline \multirow{3}{*}{ Safety } & $\begin{array}{l}\text { Fatality }\left(S_{F}\right) \\
\text { (fatalities per } T M R \text { or } \\
P M R \text { ) }\end{array}$ & $\begin{array}{l}\text { Fatality occurrence } \\
\text { data }\end{array}$ & $\begin{array}{l}\text { GIS-based accident } \\
\text { information system }\end{array}$ & $\begin{array}{l}\text { FARS,TIFA, RA/IRS, } \\
\text { ASRS, MCPD* }\end{array}$ \\
\hline & $\begin{array}{l}\text { Injury Rate }\left(S_{I}\right) \\
\text { (injuries per } T M R \text { or } \\
P M R \text { ) }\end{array}$ & Injury occurrence data & $\begin{array}{l}\text { GIS-based accident } \\
\text { information system }\end{array}$ & $\begin{array}{l}\text { FARS,TIFA, RA/IRS, } \\
\text { ASRS, MCPD }\end{array}$ \\
\hline & $\begin{array}{l}\text { Property Damage }\left(S_{P}\right) \\
\text { (dollars per } T M R \text { or } \\
P M R \text { ) }\end{array}$ & Property damage data & $\begin{array}{l}\text { GIS-based accident } \\
\text { information system }\end{array}$ & $\begin{array}{l}\text { Archival accident } \\
\text { documents }\end{array}$ \\
\hline \multirow{2}{*}{$\begin{array}{l}\text { Environmental } \\
\text { Impact }\end{array}$} & $\begin{array}{l}\text { Transportation Pollutants } \\
(P) \text { (tons per TMR or } \\
P M R) \text {. }\end{array}$ & Pollutants released & $\begin{array}{l}\text { AirData database } \\
\text { Transportation energy } \\
\text { data book }\end{array}$ & $\begin{array}{l}\text { MCPD, } \\
\text { the air/water quality report }\end{array}$ \\
\hline & $\begin{array}{l}\text { Community Livability } \\
(L)\end{array}$ & $\begin{array}{l}\text { Number of affected } \\
\text { people }\end{array}$ & Survey data collection & N/A \\
\hline \multirow[t]{2}{*}{$\begin{array}{l}\text { Long Term Cost } \\
\text { Efficiency }\end{array}$} & $\begin{array}{l}\text { Vehicle Operation Cost } \\
(V C) \\
(\text { dollars per } T M R \text { or } \\
P M R)\end{array}$ & $\begin{array}{l}\text { Gas consumption rate } \\
\text { Labor, gas, vehicle } \\
\text { insurance, vehicle } \\
\text { maintenance cost, } \\
\text { vehicle deprecation } \\
\text { cost and other cost } \\
\end{array}$ & $\begin{array}{l}\text { Regional vehicle } \\
\text { operation cost related } \\
\text { study }\end{array}$ & $\begin{array}{l}\text { Related documents on the } \\
\text { cost involved }\end{array}$ \\
\hline & $\begin{array}{l}\text { Transportation Facility } \\
\text { Cost }(F C) \\
(\text { dollars per } T M R \text { or } \\
P M R) \\
\end{array}$ & Facility cost data & $\begin{array}{l}\text { Construction } \\
\text { expenditure }\end{array}$ & $\begin{array}{l}\text { Labor cost data } \\
\text { Raw material cost data } \\
\text { Transportation cost data }\end{array}$ \\
\hline \multirow{2}{*}{$\begin{array}{l}\text { Economic } \\
\text { Growth and } \\
\text { Employment } \\
\text { Improvement }\end{array}$} & $\begin{array}{l}\text { Economic Growth ( } E G) \\
\text { (economic growth per } \\
\text { dollar investment) }\end{array}$ & $\begin{array}{l}\text { Economic growth } \\
\text { Total investment }\end{array}$ & $\begin{array}{l}\text { Local area personal } \\
\text { income database, } \\
\text { Transportation } \\
\text { expenditure }\end{array}$ & $\begin{array}{l}\text { Economic growth related } \\
\text { study } \\
\text { National Transportation } \\
\text { Statistics }\end{array}$ \\
\hline & $\begin{array}{l}\text { Employment } \\
\text { Improvement }(J) \\
\text { (number of job years per } \\
\text { dollar investment) }\end{array}$ & $\begin{array}{l}\text { Jobs created } \\
\text { Total investment }\end{array}$ & $\begin{array}{l}\text { Specific project } \\
\text { related data, } \\
\text { Transportation } \\
\text { expenditure }\end{array}$ & $\begin{array}{l}\text { Employment related study, } \\
\text { the Complete Economic } \\
\text { and Demographic } \\
\text { Data Source, National } \\
\text { Transportation Statistics }\end{array}$ \\
\hline
\end{tabular}

*FARS: The fatality analysis reporting system. TIFA: the Trucks Involved in Fatal Accidents database; RA/IRS: The Railroad Accident/Incident Reporting System; ASRS: The Aviation Safety Reporting System; MCPD: The Marine Casualty and Pollution Database. 
Performance Measures

\section{CONCLUSIONS}

This paper proposes system-level intermodal transportation performance measures based on the needs of transportation users (interest parties) and U.S. transportation goals. The proposed measures have five major categories: mobility and reliability for travel time, safety measures, environmental impact, long term transportation cost efficiency, and economic impact. The developed measure system is user-oriented, scalable, and systematic for intermodal transportation. System-level performance measures are carefully distinguished from factors. Performance measures are used to evaluate the design or the operation of an existing system and to see how well it can satisfy its users. Factors such as capacity, facility condition, accessibility, and others, which are usually defined as performance measures in the literature, are controllable parameters influencing performance measures. Project prioritization and the decision of whether to conduct a project should be made based on the values of performance measures rather than these other factors. The proposed measurement system is the first one applicable to all kinds of modes. In practice, different users may choose a subset of the proposed measures according to their needs.

The highway network in the state of Mississippi is used as a case study. The case study demonstrates how to collect data and how to calculate the proposed performance measures. Though some data are available for other modes, it is difficult to collect data for all transportation modes. This paper suggests stimulating data-collection efforts for intermodal transportation. Although the measure calculation for other modes is similar to that for highway transportation, no analytic tools are currently available for intermodal transportation. For example, TransCAD does not have the railroad transportation network and does not support intermodal analysis. A complete simulation model based on the prototype of VITS (Tan et al. 2004) can help perform intermodal analysis. With the implementation of these performance measures in the VITS, the effectiveness of the intermodal aspect of the proposed performance measures can be better evaluated.

This paper proposes various indices. To facilitate decision-making in practice, they need to fit together to compare and rank alternative designs. In the literature, there are numerous methodologies to make decisions with multiple objectives, including full cost models and multiple criteria decision analysis. A full cost model is proposed by Levinson and Gillen (1998) to integrate all indices by monetizing all external costs/benefits and summing them. The Transportation Cost and Benefit Analysis Guidebook published by Victoria Transport Policy Institute (2005) provides a framework for estimating and comparing the total costs of various transportation systems, including external costs and non-market costs. The guidebook covers 20 costs including travel time, congestion, accident, air pollution, noise, road facility, and vehicle ownership and operation. Most indices proposed in this paper can be monetized by using the methodologies and data introduced in the guidebook. A full cost model can be used to compare design alternatives with a single value. After the decision-makers identify the importance of the indices, the proposed indices can be applied by using the multiple criteria decision analysis methodologies in the literature (Belton and Stewart 2002). For example, Sharifi et al. (2004) use multiple criteria decision analysis in the development and evaluation of an integrated plan for public transport system and land use development in Malaysia.

In the case study, only $10 \%$ of the within-region truck traffic was examined to compare the performances of the southern and northern regions of Mississippi. For MPOs and planning agencies to actually employ the approach introduced in the paper, expensive surveys must be conducted to fill data gaps. Although Table 2 provides some data sources to calculate the proposed performance measures, more data collection is still necessary.

In this paper, only system-level performance measures are studied. The factors influencing these measures should also be identified in the future to help transportation designers and decisionmakers take effective actions to improve transportation efficiency. 


\section{References}

Act 51 Transportation Funding Study Committee. Act 51 White Paper - State Trunklines: Performance Measures, 1999.

Belton, V. and T. Stewart. Multiple Criteria Decision Analysis: An Integrated Approach. Kluwer Academic Publishers, Boston, MA, 2002.

Bertini, R. L. and A. El-Geneidy. Using Archived Data to Generate Transit Performance Measures. Transportation Research Board, 2003.

Bertini, R. L., M. Leal, and D. J. Lovell. Generating Performance Measures from Portland's Archived Advanced Traffic Management System Data. Transportation Research Board, 2002.

BRW, Inc. CDOT Travel Demand Improvement Projects: Improvements to Mobility Performance Measure Calculations. Colorado Department of Transportation, 2000.

Bureau of Economic Analysis. Regional Economic Accounts, 2003.

Bureau of Transportation Statistics. National Transportation Statistics 2002, 2003.

Bureau of Transportation Statistics (2005a). Truck Involved in Fatal Accidents Database. Accessed at http//www.transtats.bts.gov/ on March 19, 2005.

Bureau of Transportation Statistics (2005b). Railroad Accident/Incident Reporting System. Accessed at http://itdb.bts.gov/ on March 19, 2005.

Bureau of Transportation Statistics (2005c). Marine Casualty and Pollution Database. Accessed at http://itdb.bts.gov/ on March 19, 2005.

California Department of Transportation. 1998 California Transportation Plan: Statewide Goods Movement Strategy, 1998.

Caliper Corporation. TransCAD-Transportation GIS Software. Newton, MA, 2001.

Cambridge Systematics. Performance-Based Planning Manual. NCHRP Report 8-32(2). Transportation Research Board, National Research Council, Washington D.C., 2000.

Czerniak, R., S. Gasier, and D. Gerard. The Use of Intermodal Performance Measures by State Departments of Transportation. USDOT, 1996.

Dumbaugh, E. and M. D. Meyer. Exploring the Relationship between Agency Performance Measures and Operations Investments in a Metropolitan Area. Transportation Research Board, 2003.

East-West Gateway Coordinating Council (St. Louis Region MPO). Goods Movement Issue Paper, 1998.

Federal Highway Administration. Examination of Transportation Industry Productivity Measures. Conference Summary Report, 1993.

Florida Department of Transportation. Report to Statewide Model Task Force on Freight Modeling and Forecasting Techniques, 1998.

Hagler Bailly Services, Inc. Measuring Improvements in the Movement of Highway and Intermodal Freight. Federal Highway Administration, 2000.

Hickling Lewis Brod, Inc. Workshop on Productivity Performance Indicators: Report of Proceedings. USDOT, 1998.

Indiana Department of Transportation. Economic Performance Measures: A Technical Report from The I-69 Evansville-to-Indianapolis Study, 2000.

International Energy Agency. The Road from Kyoto, 2000. 
Performance Measures

Jin, M., K. Liu, and B. Eskioglu. "Routing with Early Ordering for Just-In-Time Manufacturing Systems.” Lecture Notes in Computer Science 3982, (2006): 720-728.

Jones, C., D. Murray, and J. Short. Methods of Travel Time Measurement in Freight-Significant Corridors. Transportation Research Board, 2005.

Kassoff, H. “Implementing Performance Measurement in Transportation Agencies.” Proceedings 26 of Performance Measures to Improve Transportation Systems and Agency Operations. Transportation Research Board, 2001.

Levinson, D. and D. Gillen. “The Full Cost of Intercity Highway Transportation.” Transportation Research -D 3:4, (1998): 207-223.

Lindley, J. A. "Urban Freeway Congestion: Quantification of the Problem and Effectiveness of Potential Solution.” Journal of the Institute of Transportation Engineer 57(1), (1987): 27-32.

Maritime Administration. Report to Congress on the Performance of Ports and the Intermodal System, 2005.

Metropolitan Transportation Commission. Performance Measures Report for the 2001 Regional Transportation Plan for the San Francisco Bay Area, 2001.

Meyer, M. D. "Measuring That Which Cannot be Measured (At Least According to Conventional Wisdom)." Proceedings 26 of Performance Measures to Improve Transportation Systems and Agency Operations. Transportation Research Board, 2001.

Ministry of Environment and Energy and National Environmental Research Institute. Indicators and Performance Measures for Transportation, Environment, and Sustainability in North America. Report from a German Marshall Fund Fellowship, 2000.

National Aeronautics and Space Administration (NASA). Aviation Safety Reporting System (ASRS). Accessed at http://asrs.arc.nasa.gov/main htm on July 17, 2004.

Pickell, S. and L. Neumann. "Use of Performance Measures in Transportation Decision-making." Proceedings 26 of Performance Measures to Improve Transportation Systems and Agency Operations. Transportation Research Board, 2001.

Public Purpose. "U.S. Urban Freeway Cost per Person Mile: 1996.” Highway \& Motorway Fact Book, 2001.

Rutherford, G. S. "Multimodal Evaluation of Passenger Transportation.” Transportation Research Board, National Research Council. NCHRP Synthesis 201, 1994.

Schrank, D. and T. Lomax. The 2005 Urban Mobility Report. Texas Transportation Institute, 2005.

Shaw, T. ITS Program Performance Measures: ITS Corridor Master Plans for Florida's Principal FIHS Limited-Access Corridors. Florida Department of Transportation, 2002.

M. A. Sharifi, L. Boerboom, and K. B. Shamsudin. "Application of Multiple Criteria Decision Analysis in Developing an Integrated Plan for Public Transport System and Land Use Development in Klang Valley, Malaysia.” The 17th International Conference on Multiple Criteria Decision Analysis, 2004.

Tan, A., B. O. Bowden, and Y. Zhang. Virtual Simulation of Statewide Intermodal Freight Traffic. Transportation Research Board, 2004.

Thompson, B. "Performance Evaluation of Florida's Public Transit Systems.” Proceedings 26 of Performance Measures to Improve Transportation Systems and Agency Operations. Transportation Research Board, 2001.

U.S. Department of Transportation. TEA-21-Transportation Equity Act for the $21^{\text {st }}$ Century: Moving Americans into the 21 ${ }^{\text {st }}$ Century, 1998. 
U.S. Department of Transportation. Performance Report for the Year 2001 and Performance Plan for the Year 2003, 2002.

U.S. Department of Transportation. Human and Natural Environment, U.S. DOT Performance Plan for 2004, 2003.

U.S. Department of Transportation. Fatality Analysis Reporting System (FARS). Accessed at http:// www-fars nhtsa.dot.gov/ on July 10, 2004.

U.S. Environmental Protection Agency. Air Pollution Data (AirData). Accessed at http://www.epa. gov/air/data/geosel.html on August 20, 2005.

U.S. Environmental Protection Agency. U.S. Emissions Inventory 1999, 1999.

U.S. Environmental Protection Agency. MOBILE 6 Vehicle Emission Modeling Software. Accessed at http://www.epa.gov/otaq/m6.htm on December 12, 2004.

U.S. House of Representatives. The Intermodal Transportation Efficiency Act of 1991 (ISTEA), 1991.

U.S. Senate. Government Performance and Results Act, 1993.

Vantuono, W. C. “Compare Apples to Oranges.” Railway Age, August 1, 2005.

Victoria Transport Policy Institute. Transportation Cost and Benefit Analysis Guidebook, 2005.

Washington DOT. Highway Construction Cost Comparison Survey, 2002.

Washington DOT. WSDOT's Congestion Measurement Approach: Learning from Operation Data, 2003.

Weisbrod, G. and B. Weisbrod. Transportation Research Circular 477. Transportation Research Board, 1997.

Woods and Pool Economics. The Complete Economic and Demographic Data Sources (CEDDS). Washington D.C, 2001.

Zhang, Y., R. O. Bowden, and A. J. Allen. Intermodal Transportation Planning Using Commodity Flow Data. National Center for Intermodal Transportation and Mississippi Department of Transportation, 2003.

Mingzhou Jin is an assistant professor in the Industrial and System Engineering Department at Mississippi State University. He received his B.S. and M.S. from Zhejiang University and Ph.D. from Lehigh University. His research interest areas include operations research, transportation, logistics, and supply chain management. He is currently the co-director of the Logistics and Transportation Engineering Lab at Mississippi State University and has conducted projects funded by the U.S. Department of Transportation, the U.S. Department of Homeland Security, the Mississippi Department of Transportation, the Center of Advanced Vehicular Systems, East Mississippi Business Development Corporation, Distribution \& Auto Services, K\&S Customer Warehousing Inc, and others. He is a member of INFORMS and IIE.

Haiyuan Wang is a Ph.D. student in the Department of Decision Sciences and Engineering Systems at Rensselaer Polytechnic Institute. He received his B.S. from Tongji University, China, and his masters from Mississippi State University and Pennsylvania State University. His research interests are primarily in operations research, statistics, simulation, and their applications in transportation, logistics, and engineering management. He is currently involved in a research project developing risk management decision support tools for a multinational logistics business. He is a member of INFORMS. 